\title{
IAMJ
}

INTERNATIONAL

AYURVEDIC

MEDICAL JOURNAL

ISSN: 2320-5091

Impact Factor: 6.719

\section{AYURVEDIC PERSPECTIVE OF SHLESHMAJA KRIMI WSR TO INTESTINAL HELMINTHS}

\author{
$\underline{\text { Rashi Dhasmana }}^{1}, \underline{\text { Sanjay KumarSingh }}^{2}, \underline{\text { Ila Tanna }}^{3}$ \\ MD Scholar ${ }^{1}$ Associate Professor ${ }^{2}$ Associate Professor $^{3}$ \\ Department of Rog Nidan Evum Vikriti Vigyan \\ Rishikul Campus, UAU, Haridwar, Uttarakhand, India
}

Corresponding Author: ukrashi007@gmail.com

\section{https://doi.org/10.46607/iamj1809062021}

(Published Online: June 2021)

Open Access

(C) International Ayurvedic Medical Journal, India 2021

Article Received:30/05/2021 - Peer Reviewed:09/06/2021 - Accepted for Publication:10/06/2021

Check for updates

\begin{abstract}
Krimi has been known as disease causing agent since ancient times. The vast details of pathology of each Krimi is not found in our classics but the classification, morphology, etc are very well described. Acharya Charaka classified Krimi into twenty types which come under two broad groups -Bahya and Abhyantara. Abhyantara Krimi being sub-classified into Shleshmaja, Purishaja \& Raktaja Krimi. Among these varieties of Krimi, Shleshmaja Kri$m i$ can be closely correlated with Intestinal Helminths. Modern Pharmacology consists of a variety of anthelmintic drugs which are efficient enough to treat helmintic infections but still recurrence of these infections is seen very commonly. The three-fold treatment of Ayurveda - Apkarshana, Prakruti Vighata \& Nidana Parivarjana, as mentioned in Charaka Samhita can prove to be very helpful in eradicating such infections or Shleshmaja Krimiroga. Present study is an attempt to understand about Shleshmaja Krimi wsr to Intestinal Helminths.
\end{abstract}

Keywords: Shleshmaja, Krimi, Intestinal, Helminths, Treatment. 


\section{INTRODUCTION}

The derivation of the word Krimi is available in various lexicons. Popular Sanskrit dictionaries Amarakosa, Halayudhakosa and Vachaspatyama state that the word is derived from the root "Kramu" which means to step or to walk. ${ }^{1}$ The different Acharya have made Classifications of Krimi under various headings. Acharya Sushruta categorized Krimi as Drishta and Adrishta variety as in Vedic literature. Acharya Charaka categorized them as Sahaja andVaikarika, with detailed description of Vaikarika variety. The Acharya mentioned the number of Krimi as twenty while Harita stated as thirteen. Sharangdhara mentioned as twenty-two. While rest of Acharya, like Vagbhata, Madhavakara and Bhavamishra followed Acharya Charaka. Based on site of localization, Acharya Charaka and Acharya Harita further made divisions like Bahya and Abhyantara. The Abhyantara variety being further classified by Acharya Charaka as Shleshmaja, Raktaja and Purishaja Krimi.Among these varieties, Shleshmaja Krimi can be closely correlated with Intestinal helminths based on its morphology, site of localization and signs \& symptoms produced by it. There are a variety of broad spectrum modern anthelmintic drugs through whichsuch infections can be treated efficiently. But recurrence of helmintic infections is seen very commonly in the society. So, there is a need of an alternative treatment approach to arrest the recurrence of helmintic infections and eradicate them. Acharya Charaka has given a threefold line of treatment of Krimiroga as: Apakarshana, Prakruti Vighata, \& Nidana Parivarja$n a$. This can prove to be an alternative treatment of Intestinal helmintic infections or Shleshmaja Krimiro$g a$ in order to completely arrest their recurrence.

\section{MATERIAL AND METHODS}

For this conceptual study, various Ayurvedic Samhitas like Charaka Samhita, Sushruta, Samhita, Ashtanga Hridaya, Madhavnidana, Bhavaprakash and some articles have been reviewed.

\section{INTESTINAL HELMINTHS ${ }^{2}$ /WORM INFESTA- TION}

The Helminths are multicellular, bilaterally symmetrical animals having three germ layers. Based on their shape, they are divided into two broad groups belonging to the Phylums- Nemathelminths (Class Nematoda - Ascaris lumbricoides, Ancyclostoma duodenale, etc.) and Platyhelminths (Class Trematoda - Fasciola hepatica, etc. and Class Cestoda - Taenia solium, T. saginata, etc.).Worm infestation refers to the worms that live as parasites in the human body and are one of the main causes of diseases associated with health and nutrition problems beyond just Gastro-intestinal tract (GIT) disturbances. More than 1.5 billion people, or $24 \%$ of the world's population, are infected with helminth infections worldwide. Infections are widely distributed in tropical and subtropical areas, with the greatest numbers occurring in sub-Saharan Africa, the Americas, China \& East Asia.Over 267 million preschool-age children and over 568 million school-age children live in areas where these parasites are intensively transmitted and need treatment and preventive interventions. ${ }^{3}$ The infections may be transmitted in several ways. For instance, while some of the parasitic worms (larvae) such as Taenia solium infects human beings following ingestion of contaminated pork, others, like some species of nematodes, are soiltransmitted and often affect younger children. The lesions caused by such parasites may be localized or may extend to distant parts of the host's body. The way in which damage may be produced includes trauma or physical damage, lytic necrosis, stimulation of host's tissue reactions, toxic and allergic phenomena, and the opening of pathways for entry of other pathogens into the tissues. Also, the masses of large worms like Ascaris may produce acute intestinal obstruction, may occlude the lumen of the appendix or the common bile duct, may cause perforation of the intestinal wall or may penetrate liver parenchyma and even the lungs. Hence, they not only cause symptoms related to GIT like nausea, vomiting, diarrhea, etc., but others also like anaemia, skin irritation, cough, fever, weight loss or emaciation, etc. Infections may range from mild to serious life-threatening ones. Though most of the helminth infections can be prevented by good hygiene, there are a wide range of anthelmintic drugs mentioned in Modern Pharmacology 
e.g., Broad spectrum Benzimidazoles (Albendazole and Mebendazole), Macrocyclic lactones (such as Ivermectin), Praziquantel, Oxamniquine, Pyrantel, Artemisinins and derivatives, etc. ${ }^{4}$

Though all these drugs efficiently act on the Helminths still all the available data of prevalence of helminths remains almost the same even after aggressive implementation of eradication programs with mass administration of anthelmintic drugs to the popu- lation. And there is a need for an alternative treatment which can help eradicate these infections.

\section{SHLESHMAJA KRIMI}

The different aspects of Shleshmaja Krimi like number of types, their names, site of localization, morphological features and their colours have been described by different Acharya with a few variations in them. All these aspects have been incorporated into the following table -

Table 1: Different aspects of Shleshmaja Krimi

\begin{tabular}{|c|c|c|c|}
\hline Aspect & Charaka & Sushruta & Vagbhata \\
\hline No. of Types & 7 & 6 & 7 \\
\hline Name & $\begin{array}{l}\text { Antrada } \\
\text { Udarada } \\
\text { Hrudayachara } \\
\text { Darbhapushpa } \\
\text { Saugandhika } \\
\text { Mahaguda } \\
\text { Curu }\end{array}$ & $\begin{array}{l}\text { Mahapushpa } \\
\text { Praluna } \\
\text { Cipita } \\
\text { Pipilika } \\
\text { Daruna } \\
\text { Darbhapushpa }\end{array}$ & $\begin{array}{l}\text { Antrada } \\
\text { Hrudayada } \\
\text { Udaravesta } \\
\text { Curu } \\
\text { Mahaguda } \\
\text { Sugandha } \\
\text { Darbhakusuma }\end{array}$ \\
\hline Site & Amashaya, spreads up \& down & Amashaya & Amashaya, spreads everywhere \\
\hline Morphology & $\begin{array}{l}\text { Prithu, Bradhna, } \\
\text { Gandupada, Anu, Dirgha, Tantu }\end{array}$ & $\begin{array}{l}\text { Romasha, Sapucha, Dhanyanku- } \\
\text { rakara, Tanu }\end{array}$ & $\begin{array}{l}\text { Prithu, Bradhna, Gandupada, } \\
\text { Anu, Dirgha, Tantu, Dhan- } \\
\text { yankurakara }\end{array}$ \\
\hline Colour & Shweta, Tamravbhasa & Shukla, Shyava Mandal & Shweta, Tamravbhasa \\
\hline
\end{tabular}

\section{NIDANA (ETIOLOGICAL FACTORS)}

The Nidana of Shleshmaja Krimi mentioned by different Acharya actually contribute in increasing and vitiating the Kapha Dosha. For example, Acharya Charaka included Ksheer (Milk and milk products); Gudh (Jaggery); Tila (Sesame);Matsya (Fish); Anoopa Mamsa (Flesh of aquatic animals); Pishtanna (Flour of Urad or other heavy grains);Kusumbhasneha;Ajeerna (Partially cooked), Puti (Putrefacted), Klinna (Fermented), Sankeerna (Contaminated), Virudha (Incompatible) and Asatmya (unwholesome) Bhojana as Nidana of Shleshmaja Krimi ${ }^{5}$ Acharya Madhava added Dadhi and Shukta ${ }^{6}$ to this list. Along with this, Sak$t u^{7}$ (powdered barley) and Navodana (newly harvested rice) have been included by Acharya Vagbhata.

\section{LAKSHANA (SYMPTOMS)}

Acharya Charaka mentioned Hrillasa (Nausea), Asyasamsravana (Excessive Salivation), Arochaka (lack of appetite), Avipaka (Indigestion), Jvara (Fever), Murchha (Unconsciousness), Jrimbha (Yawning), Kshavathu (Sneezing), Anaha (Distension of abdomen with constipation), Angamarda (Bodyache), Chhardi (Vomiting), Karshya (Emaciation/weight loss) and Parushya ${ }^{8}$ (Dryness of skin) as Lakshana of ShleshmajaKrimi. Other than these, Acharya Madhava added Peenasa ${ }^{9}$ (Chronic Rhinitis) also to this and $\mathrm{Kasa}^{10}$ (cough) has been included in this by Acharya Bhavaprakasha. While Acharya Sushruta mentioned Shiroroga (headache or other disorders related to head), Hridroga (palpitation or other heart related disorders), Vamathu (vomiting) and Pratishyayal (runny nose) as some other Nidana. 


\section{SAMPRAPTI}

The Samprapti of Krimiroga has not been described by any of the Acharya. But it can be derived like this : Kapha Vardhak Nidan Sevan
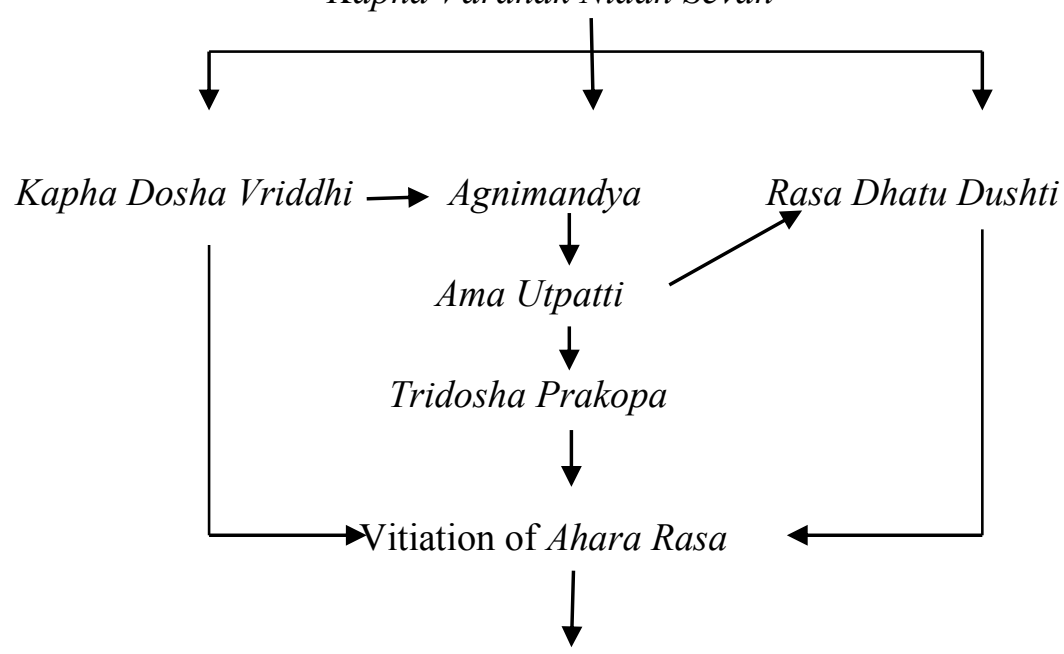

Kha-Vaigunya in Amashaya

(Stomach, Duodenum, Jejunum, Ileum)

Dosh-Dushya Sammurchana

Shleshmaja Krimi Utpatti

(Germination of cyst/ova \& Multiplication of worms)

Shleshmaja Krimiroga

\section{SAMPRAPTI GHATAKA (PATHOLOGICAL} FACTORS)

- Dosha: Kapha Pradhana Tridosha

- Dushya: Rasa

- Srotasa:Rasavaha, Annavaha

- Adhishthana: Amashaya

- Srotodushti: Sanga

- Agnidushti: Mandagni.

TREATMENT OF KRIMI: Acharya Charaka has given a 3-fold line of treatment of Krimi as: Apakarshana, Prakruti Vighata, \& Nidana Parivarja$n a .^{12}$

1. Apakarshana: It means expulsion of Krimi from the gut with the help of various purification procedures like Shirovirechana, Vamana, Virechana and Asthapanavasti.

2. Prakruti Vighata: Here Prakruti word is used for Utpadaka Karana i.e., causative factor and Vighata means destruction of the causative agent.
Drugs having Katu (pungent), Tikta (bitter), Kashaya (astringent) Rasa (taste), Ushna (hot) virya (potency) and Kshara (alkali)-like properties are advised to be used here. Kapha providesfavourable environment for growth of Krimi. Hence, the drugs acting against such environment does the action of Prakruti Vighata.

3. Nidana Parivarjana: This forms an important mode of treatment. It includes avoidance of diet and habits which favour the production of Krimi in the body. It stops the growth of Krimi as well as reduces the chances of reinfection. All the factors mentioned under the heading of Nidana fit into this category.

CORRELATION ${ }^{13}$ : Some previous workers have tried to correlate Ayurvedic nomenclature of Shleshmaja Krimi with those of the recognized Intestinal Helminths as per modern science. 
Table 2: Correlation made by previous research workers.

\begin{tabular}{|l|l|l|l|}
\hline S. No. & Name of ShleshmajaKrimi & Name of Helminth correlated with & Name of Previous Worker \\
\hline 1. & Antrada & Hookworm & $\begin{array}{l}\text { Ghai Y.S., Pandey M.P., } \\
\text { Goyal H.R., Shastri S., } \\
\text { Lathiya V.N. }\end{array}$ \\
\hline 2. & Churu & E.vermicularis/T.saginata & Adhikari Y./Sharma O.P. \\
\hline 3. & Chipita & $\begin{array}{l}\text { T. solium and saginata, } \\
\text { H.nana, D.latum }\end{array}$ & $\begin{array}{l}\text { Ghai Y.S., Sharma O.P., } \\
\text { Lathiya V.N. }\end{array}$ \\
\hline 4. & Darbhakusuma & Threadworm & Pandey M.P. \\
\hline 5. & Hridayachara & $\begin{array}{l}\text { A.duodenale, } \\
\text { T. solium, T.saginata, } \\
\text { E.vermicularis, } \\
\text { A.duodenale, } \\
\text { A.lumbricoides }\end{array}$ & $\begin{array}{l}\text { Sharma R.D. } \\
\text { Solanki S.S. }\end{array}$ \\
\hline 6. & Mahaguha & A.lumbricoides & $\begin{array}{l}\text { Pandey M.P., Goyal H.R., } \\
\text { Shastri S., TiwariL.K.,Pandey R.N., } \\
\text { Vajpai D.K. }\end{array}$ \\
\hline 7. & Praluna & Sharma O.P. \\
\hline 8. & Saughandhika & Tapeworms & Pandey M.P. \\
\hline 9. & Udarada & Whipworm & Sharma R.D. \\
\hline 10. & Udarveshta & T.saginata, T.solium, H.nana & Sharma R.D. \\
\hline
\end{tabular}

Although most of the scholars do not explain the basis of this correlation. But the Shleshmaja Krimi and Intestinal helminths have many aspects in common like-

$\checkmark$ Site of localization: Amashaya i.e. stomach, duodenum, jejunum and ileum.

$\checkmark$ Some morphological features: e.g., Gandupada - Roundworm i.e., A. lumbricoides.

$\checkmark$ Signs \& symptoms: e.g., Hrillasa (Nausea), Chhardi (Vomiting), Jwara (Fever), Karshya (Emaciation), Kasa (Cough), etc.

\section{DISCUSSION}

From the above description we can conclude that Krimi has been one of the causes of sickness since ages. The vast details of pathology of each and every Krimi is not found in our classics, may be due to lack of sophisticated devices or investigations as available at present times. But there is a lot of description about various aspects of Krimi like their classification, sites of localization, etiological factors, morphology and signs \& symptoms produced by them on entering the human body. Among the different types of Krimi, the Shleshmaja Krimi has been correlated with Intestinal helminths due to similarities in their various aspects like their site of localization in the infected body, some morphological features and the signs \& symptoms caused due to their infection. There are many broad-spectrum anthelmintic drugs mentioned in Modern Pharmacology which are efficient enough to kill these organisms. But still recurrences of such infections are seen all the time especially in schoolgoing children of developing countries. So, there is a need for a different approach and Ayurveda can be very helpful in that. The line of treatment of Krimi as described by Acharya Charaka is three fold which includes Apkarshana (expulsion or removal of the Krimi or worm from the body), Prakruti Vighata (destruction of the favourable environment for the growth of Krimi) and Nidana Parivarjana (avoiding the factors required for growth or entrance of Krimi into the body). This threefold treatment can definitely help eradicate helmintic infections or Shleshmaja Krimiroga.

\section{CONCLUSION}

In medical science, sickness and death have always generated challenge to the human intellect. From very early times, it is speculated that diseases may result 
from invasion of the body by external infectious organisms acknowledged as Krimi. Shleshmaja Krimi which are correlated with Intestinal Helminths have been a major cause of infections associated with health and nutrition problems especially among school-going children. It is a silent epidemic that destroys the health, well-being \& learning potential of millions of children in many developing countries today. Even after mass administration of modern anthelmintic drugs under eradication programs, recurrence of helmintic infections is very common. In this scenario, the Ayurvedic approach which includes $A p$ karshana, Prakruti Vighata and Nidana Parivarjana can prove to be very beneficial to the society and can help eradicate this mammoth challenge.

\section{REFERENCES}

1. Vaishnavi G. Tengse, Udara Krimi (Intestinal Helminths) in Etiopathogenesis of Pandu, RNVV, IPGT \& RA, GAU, Jamnagar, year 2010, pg-17.

2. P. Chakraborty, Textbook of Medical Parasitology, New central book agency (P) Ltd, Kolkata, 2nd edition January, 2005

3. https://www.who.int/news-room/factsheets/detail/soil-transmitted-helminth-infections, $2^{\text {nd }}$ March 2020

4. en.m.wikipedia.org/wiki/Anthelmintic.

5. Pandit Kashinath Shastri and Dr Gorakhnath Chaturvedi, Hindi commentary on Charaka Samhita of Agnivesha revised by Charaka and Dridhbala, Volume 1, VimanSthana, Chapter 7Chaukhamba Bharati Academy, Varanasi, Reprint 2012, pg-726.

6. Shri Yadunandan Upadhyaya, Madhav NidanamMadhukosh commentary with Hindi VidyotiniVolume 1, Chaper 7, Chaukhamba Sanskrit Sansthana, Varanasi, Reprint 2018. pg. 240.

7. Dr Brahmananda Tripathi Ashtanga Hridayama of Srimadvagbhata, Chaukhamba Sanskrit Pratishthan, Delhi, Reprint 2019, pg-534.

8. Pandit Kashinath Shastri and Dr Gorakhnath Chaturvedi, Hindi commentary on Charaka Samhita of Agnivesha revised by Charaka and Dridhbala, Volume 1, Viman Sthana, Chapter 7Chaukhamba Bharati Academy, Varanasi, Reprint 2012, pg-727.

9. Shri Yadunandan Upadhyaya, Madhav NidanamMadhukosh commentary with Hindi Vidyotini, Vol- ume 1, Chaper 7, Chaukhamba Sanskrit Sansthana, Varanasi, Reprint 2018. pg. 241.

10. Harihar Prasad Pandey, Bhavprakasha - VidyotiniHindi commentary Volume 2, Madhyam Khanda, pg-94-98.

11. Dr AmbikaduttaShastri,Sushruta Samhita,Volume 2,Uttaratantra, Chapter 54,Chaukhamba Sanskrit Sansthana, Varanasi, Reprint 2012, pg-510.

12. Pandit Kashinath Shastri and Dr Gorakhnath Chaturvedi, Hindi commentary on Charaka Samhita of Agnivesha revised by Charaka and Dridhbala, Volume 1, VimanSthana, Chapter 7Chaukhamba Bharati Academy, Varanasi, Reprint 2012, pg-728.

13. Inchulkar Shrikant et al., A study on KrimighnaDashemani with special reference to Shobhanjana, GAU, Jamnagar, 1989, pg 100-102.

\section{Source of Support: Nil \\ Conflict of Interest: None Declared}

How to cite this URL: Rashi Dhasmana et al: Ayurvedic Perspective Of Shleshmaja Krimi Wsr To Intestinal Helminths. International Ayurvedic Medical Journal \{online\} 2021 \{cited June, 2021\} Available from: http://www.iamj.in/posts/images/upload/1260_1265.pdf 